\title{
Compensatory alterations of insulin signal transduction in liver of growth hormone receptor knockout mice
}

\author{
F P Dominici, G Arostegui Diaz, A Bartke ${ }^{1}$, J J Kopchick ${ }^{2}$ \\ and D Turyn
}

Instituto de Química y Fisicoquímica Biológicas (UBA-CONICET), Facultad de Farmacia y Bioquímica, Junin 956, 1113, Buenos Aires, Argentina

${ }^{1}$ Department of Physiology, School of Medicine, Southern Illinois University, Carbondale, Illinois 62901-6512, USA

${ }^{2}$ Edison Biotechnology Institute and Department of Biomedical Sciences, College of Osteopathic Medicine, Ohio University, Athens, Ohio 45701, USA

(Requests for offprints should be addressed to D Turyn, Instituto de Química y Fisicoquímica Biológicas (IQUIFIB), Facultad de Farmacia y Bioquímica, Universidad de Buenos Aires, Junin 956 (1113), Buenos Aires, Argentina; Email: dturyn@qb.ffyb.uba.ar)

\begin{abstract}
Growth hormone $(\mathrm{GH})$ deficiency is associated with increased sensitivity to insulin, but the molecular mechanisms involved in this association are poorly understood. In the current work, we have examined the consequences of the absence of the biological effects of GH on the first steps of the insulin signaling system in vivo in liver of mice with targeted disruption of the GH receptor/GH binding protein gene (GHR-KO mice). In these animals, circulating insulin concentrations are less than $4 \mu \mathrm{IU} / \mathrm{ml}$, and glucose concentrations are low, concordant with a state of insulin hypersensitivity. The abundance and tyrosine phosphorylation state of the insulin receptor (IR), the IR substrate-1 (IRS-1), and Shc, the association between
\end{abstract}

IRS-1 and the p85 subunit of phosphatidylinositol (PI) 3-kinase, the IRS-1- and the phosphotyrosine-associated PI 3-kinase in liver were examined. We found that, in liver of GHR-KO mice, the lack of GHR and GH effects is associated with: (1) increased IR abundance, (2) increased insulin-stimulated IR tyrosine phosphorylation, (3) normal efficiency of IRS-1 and Shc tyrosine phosphorylation and (4) normal activation of PI 3-kinase by insulin. These alterations could represent an adaptation to the low insulin concentrations displayed by these animals, and may account for their increased insulin sensitivity.

Journal of Endocrinology (2000) 166, 579-590

\section{Introduction}

Insulin induces a wide diversity of growth and metabolic responses in many cell types. It acts as a major regulator of glucose, lipid and protein metabolism in liver and other peripheral tissues (Cheatham \& Kahn 1995). After insulin binds to the $\alpha$-subunit of the insulin receptor (IR), the tyrosine kinase activity that resides in the $\beta$-subunit becomes activated, leading to autophosphorylation of tyrosine residues in several regions of the intracellular $\beta$-subunit and further activation of its tyrosine kinase towards intracellular substrates (Kasuga et al. 1982, White 1997). One of the principal substrates of the IR kinase is the insulin receptor substrate-1 (IRS-1), a $185-\mathrm{kDa}$ cytosolic protein with many tyrosine phosphorylation sites which functions as the interfaces between the receptor and several Src homology 2 (SH2) domain-containing proteins (Sun et al. 1991), and has been shown to mediate multiple signaling pathways (White 1997). Phosphatidylinositol (PI) 3-kinase is one of the $\mathrm{SH} 2$ domain-containing proteins. When tyrosine phosphorylated, IRS-1 binds the p85 subunit of PI 3-kinase (p85), thereby activating this enzyme (Backer et al. 1992, Lavan et al. 1992). PI 3-kinase activation seems to be a central event in the insulin action pathway (Shepherd et al. 1998). Activation of the mitogen-activated protein (MAP) kinase cascade is another major insulin signaling pathway. Although it has been shown that IRS-1 participates in this pathway, several reports indicate that the transforming protein Shc (Src homology $2 / \alpha$-collagen related) is the main signaling molecule involved (Sasaoka et al. 1994, Yamauchi \& Pessin 1994, White 1997).

It is accepted that $\mathrm{GH}$ modulates tissue responses to insulin. Thus, whereas GH excess leads to an impairment of insulin sensitivity and hyperinsulinemia (Bratusch-Marrain et al. 1982, Davidson 1987, Rizza et al. 1982), GH-deficiency is associated with increased insulin sensitivity, decreased insulin secretion and decreased fasting glucose concentrations (Hopwood et al. 1975, Bougneres et al. 1985, Daugaard et al. 1999). GH biological effects are initiated by binding and dimerization of its membrane receptor (Thomas 1998). The GH receptor (GHR) lacks intrinsic tyrosine kinase activity (Argetsinger et al. 1993, Thomas 1998), but instead stimulates the activity of the JAK2 tyrosine kinase (Argetsinger et al. 1993). After the activation of JAK2, several intracellular 
proteins undergo tyrosine phosphorylation (Thomas 1998). One of them is IRS-1, which has been shown to be tyrosine phosphorylated and associated with the p85 subunit of PI 3-kinase in response to $\mathrm{GH}$, both in cultured cells (Souza et al. 1994, Argetsinger et al. 1995, Ridderstråle et al. 1995) and in target tissues of intact animals (Yamauchi et al. 1998, Thirone et al. 1999).

GHR/GH binding protein gene knockout (GHR-KO) mice, which are an animal model of the Laron syndrome, have recently been produced (Zhou et al. 1997). In these mice, although $\mathrm{GH}$ is secreted in large quantities, its biological effects are absent because of the lack of GHR. We have previously reported that insulin-like growth factor-1 was not detectable in the circulation of these animals (Zhou et al. 1997). Thus they appear to be an excellent tool with which to study how the lack of GH effects influences the insulin signaling system in intact animals. Consequently, in the present study, we have examined the first steps of insulin action in liver of GHR-KO mice. We evaluated the tyrosine phosphorylation status of the IR and its substrates IRS-1 and Shc, the association between IRS-1 and p85, and the IRS-1- and total phosphotyrosine-associated PI 3-kinase activity after insulin stimulation in vivo. Furthermore, the abundance of the IR, IRS-1, Shc, and p85 in this tissue was determined.

\section{Materials and Methods}

\section{Materials}

The reagents and apparatus for SDS-PAGE and immunoblotting were obtained from Bio-Rad (Richmond, CA, USA). HEPES, Tris, phenylmethylsulfonyl fluoride (PMSF), aprotinin, ATP, phosphatidylinositol, phosphatidylinositol 4-monophosphate, Triton X-100, Tween 20, porcine insulin, and bovine serum albumin (fraction V) (BSA) were obtained from Sigma Chemical Co. (St Louis, MO, USA). Silica gel thin-layer chromatography plates were from Merck (Darmstadt, Germany). Protein A-Sepharose $6 \mathrm{MB}$ was from Pharmacia (Uppsala, Sweden). Iodine-125-labelled protein A was purchased from ICN Biomedicals (Costa Mesa, CA, USA). $\left[\gamma-{ }^{32} \mathrm{P}\right]$ ATP was from Dupont-NEN (Boston, MA, USA). Immobilon $\mathrm{P}$ membranes were from Millipore (Bedford, MA, USA). The monoclonal anti-phosphotyrosine antibody ( $\alpha$ PY, PY99) and the polyclonal anti-IR $\beta$-subunit antibody ( $\alpha$ IR, C-19) were purchased from Santa Cruz Biotechnology, Inc. (Santa Cruz, CA, USA). The anti-rat carboxy-terminal IRS-1 antibody ( $\alpha$ IRS-1), the antibody to the $\mathrm{p} 85$ subunit of PI-3-kinase ( $\alpha \mathrm{p} 85$ ), and the anti-Shc antibody $(\alpha \mathrm{Shc})$ were from Upstate Biotechnology (Lake Placid, NY, USA).

\section{Animals}

GHR-KO mice (-/-) were obtained as described previously (Zhou et al. 1997). Adult normal female mice bred in our animal facility were mated with either GHR-KO male mice or male mice with the $+/$ - genotype, and the resulting female GHR-KO mice and non-GHR-KO littermates (control mice) were used in the present experiments. Animals were housed in a room with a controlled photoperiod of $12 \mathrm{~h}$ light : darkness (lights on from 0600 to $1800 \mathrm{~h}$ ) and a temperature of $22-23{ }^{\circ} \mathrm{C}$. Mice were given free access to a nutritionally balanced diet (LabDiet, PMI Feeds, Inc., St Louis, MO, USA) and tap water.

\section{Measurement of plasma insulin and glucose concentrations}

Fasting plasma insulin concentration was determined using a solid-phase radioimmunoassay kit from DPC (Diagnostic Products Inc., Los Angeles, CA, USA).

Plasma glucose was measured with the glucose oxidase procedure (Trender; Sigma Chemical).

\section{Methods}

Female GHR-KO mice and their normal siblings (3-5 months of age) were starved overnight, and $15 \mathrm{~min}$ before the experiment they were anesthetized by the intraperitoneal administration of $100 \mathrm{mg}$ of sodium pentobarbital per $\mathrm{kg}$ of body weight. After anesthesia was induced, the portal vein was exposed and $10 \mathrm{IU}$ insulin per $\mathrm{kg}$ body weight in normal saline $(0.9 \% \mathrm{NaCl})$ in a final volume of $0.1 \mathrm{ml}$ was injected via this vein. GHR-KO and control mice that had been injected with diluent only were used to evaluate changes under basal conditions. Approximately $50 \mathrm{~s}$ after injection, the liver was removed, coarsely minced, and homogenized in 10 volumes of solubilization buffer A (1\% Triton, $100 \mathrm{mM}$ Tris ( $\mathrm{pH}$ 7.4), $100 \mathrm{mM}$ sodium pyrophosphate, $100 \mathrm{mM}$ sodium fluoride, $10 \mathrm{mM}$ EDTA, $10 \mathrm{mM}$ sodium vanadate, $2 \mathrm{mM}$ PMSF, and $0 \cdot 1 \mathrm{mg} / \mathrm{ml}$ aprotinin) at $4{ }^{\circ} \mathrm{C}$. Liver extracts were centrifuged at $100000 \times g$ at $4{ }^{\circ} \mathrm{C}$ in a Beckman 90 Ti rotor (Palo Alto, CA, USA) for $1 \mathrm{~h}$ to eliminate insoluble material. Protein concentration was determined by the method described by Bradford (1976), and the supernatants were subjected to immunoprecipitation with $\alpha$ IR, $\alpha$ IRS- 1 and protein A-Sepharose $6 \mathrm{MB}$.

\section{Immunoprecipitation}

Liver homogenates containing $8 \mathrm{mg}$ total protein prepared as described in Methods were incubated at $4{ }^{\circ} \mathrm{C}$ overnight with $\alpha$ IR, $\alpha$ IRS- 1 or $\alpha$ Shc $(4 \mu \mathrm{g} / \mathrm{ml}$ final concentration for all antibodies). After incubation, $50 \mu \mathrm{l}$ protein A-Sepharose $(50 \%, \mathrm{vol} / \mathrm{vol})$ was added to the mixture. The preparation was further incubated with constant rocking for $2 \mathrm{~h}$ and centrifuged at 12000 r.p.m. for $1 \mathrm{~min}$ at $4{ }^{\circ} \mathrm{C}$. The precipitate was washed three times with lysis buffer. The final precipitate was boiled for $5 \mathrm{~min}$ in $60 \mu \mathrm{l}$ of reducing sample buffer (final concentrations: $62.5 \mathrm{mM}$ Tris, 10\% glycerol, 5\% 2-mercaptoethanol, 2\% SDS, 
$0.02 \%$ bromophenol blue), and stored at $-70{ }^{\circ} \mathrm{C}$ until required for electrophoresis.

\section{Immunoblotting}

Samples were subjected to SDS-PAGE on a $6 \%$ polyacrylamide gel using a Bio-Rad Mini Protean apparatus (Bio-Rad Laboratories). Electrotransfer of proteins from the gel to Immobilon P membranes was performed for $2 \mathrm{~h}$ at $100 \mathrm{~V}$ (constant) using the Bio-Rad miniature transfer apparatus in $25 \mathrm{mM}$ Tris, $192 \mathrm{mM}$ glycine, 20\% (vol/vol) methanol, and $0.02 \%$ SDS. To reduce non-specific antibody binding, the membranes were incubated at $4{ }^{\circ} \mathrm{C}$ overnight in a blocking buffer composed of Tris-buffered saline-Tween 20 (TBS-T) buffer $(10 \mathrm{mM}$ Tris $\mathrm{HCl}$ (pH 7.6), $150 \mathrm{mM} \mathrm{NaCl}$, and $0 \cdot 02 \%$ Tween 20) containing either 3\% BSA (for phosphotyrosine detection) or 5\% non-fat dry milk (for protein detection). The membranes were then incubated for $4 \mathrm{~h}$ at room temperature with $\alpha \mathrm{PY}(1 \mu \mathrm{g} / \mathrm{ml}), \alpha \operatorname{IR}(1 \mu \mathrm{g} / \mathrm{ml}), \alpha \operatorname{IRS}-1(1 \mu \mathrm{g} / \mathrm{ml})$ or $\alpha$ Shc $(1 \mu \mathrm{g} / \mathrm{ml})$ diluted in the corresponding blocking buffer. The membranes were subjected to four 5-min washes in TBS-T buffer and were then incubated with $3 \mu \mathrm{Ci}{ }^{125} \mathrm{I}$ - protein $\mathrm{A}(30 \mu \mathrm{Ci} / \mu \mathrm{g})$ in $15 \mathrm{ml}$ blocking buffer for $1 \mathrm{~h}$ at room temperature and then washed again for $60 \mathrm{~min}$ as described above. ${ }^{125}$ I-Protein A bound to antibodies was detected by autoradiography using preflashed Kodak XAR film (Eastman Kodak, Rochester, NY, USA) at $-70{ }^{\circ} \mathrm{C}$ for $6-72 \mathrm{~h}$. Band intensities were quantitated by optical densitometry (model CS-930, Shimadzu, Japan) of the developed autoradiographs.

The amount of the p85 subunit of the PI 3-kinase in aIRS-1 immunoprecipitates was evaluated by stripping the membranes and reblotting as follows: The blots that had been blotted with $\alpha \mathrm{PY}$ were rinsed, incubated in $2 \%$ SDS, $60 \mathrm{mM}$ Tris (pH 6.7), $100 \mathrm{mM}$ 2-mercaptoethanol at $50{ }^{\circ} \mathrm{C}$ for $45 \mathrm{~min}$, and reprobed again without adding additional primary antibody to check that all antibody had been removed. The membranes were then blocked for $2 \mathrm{~h}$ at room temperature with 5\% non-fat dry milk in TBS-T buffer and incubated with an antibody to the $\mathrm{p} 85$ subunit of PI-3-kinase ( $\alpha \mathrm{p} 85 ; 1: 2000$ final concentration) in TBS-T plus $1 \%$ non-fat dry milk. Bound antibodies were detected by incubation with ${ }^{125} \mathrm{I}$-protein $\mathrm{A}$ as described previously.

To determine the abundance of $\mathrm{p} 85$ in liver, equal amounts of solubilized proteins $(120 \mu \mathrm{g})$ were denatured by being boiled in reducing sample buffer, resolved by SDS-PAGE, and subjected to immunoblotting with $\alpha$ p85. Bound antibodies were detected by incubation with ${ }^{125}$ I-protein A. Quantitation of specific protein bands was performed by densitometry.

\section{Determination of PI 3-kinase activity in immunoprecipitates}

This determination was performed essentially as described previously (Dominici et al. 1999a, b). Livers of control and
GHR-KO mice that had been injected with or without insulin as described in Methods were extracted and homogenized in solubilization buffer B (50 mM HEPES (pH 7.4), $137 \mathrm{mM} \mathrm{NaCl}, 1 \mathrm{mM} \mathrm{MgCl}_{2}, 1 \mathrm{mM} \mathrm{CaCl}$, $2 \mathrm{mM} \mathrm{Na} \mathrm{VO}_{4}, 10 \mathrm{mM} \mathrm{Na} \mathrm{P}_{2} \mathrm{O}_{7}, 100 \mathrm{mM} \mathrm{NaF}, 2 \mathrm{mM}$ EDTA, $2 \mathrm{mM}$ PMSF, $2 \mathrm{mM}$ aprotinin, $2 \mathrm{mM}$ leupeptin, $10 \%$ (vol/vol) glycerol, and $1 \%$ Triton X-100) at $4{ }^{\circ} \mathrm{C}$. The homogenates were centrifuged at $100000 \mathrm{~g}$ for $1 \mathrm{~h}$ at $4{ }^{\circ} \mathrm{C}$. Liver homogenates containing $8 \mathrm{mg}$ total protein were incubated overnight at $4{ }^{\circ} \mathrm{C}$ with $\alpha \mathrm{PY}(5 \mu \mathrm{g})$ or with aIRS-1 $(4 \mu \mathrm{g})$. Immunocomplexes were collected by addition of $100 \mu \mathrm{l}$ of a $50 \%$ (vol/vol) slurry of protein A-Sepharose in phosphate-buffered saline (PBS) and further incubation for $2 \mathrm{~h}$ at $4{ }^{\circ} \mathrm{C}$. After centrifugation, bound complexes were washed three times with ice-cold PBS (pH 7.4) containing 1\% Triton X-100 and $100 \mu \mathrm{M}$ $\mathrm{Na}_{3} \mathrm{VO}_{4}$, three times in ice-cold $100 \mathrm{mM}$ Tris (pH 7·5) containing $100 \mathrm{mM} \mathrm{LiCl}$ and $100 \mu \mathrm{M} \mathrm{Na} \mathrm{VO}_{4}$, and twice with ice-cold $10 \mathrm{mM}$ Tris ( $\mathrm{pH} \mathrm{7.5)}$ containing $100 \mathrm{mM} \mathrm{NaCl}, 1 \mathrm{mM}$ EDTA, and $100 \mu \mathrm{M} \mathrm{Na}_{3} \mathrm{VO}_{4}$. The precipitates were then resuspended in a mixture containing $50 \mu \mathrm{l} 10 \mathrm{mM}$ Tris (pH 7.5) containing $100 \mathrm{mM} \mathrm{NaCl}$, $1 \mathrm{mM}$ EDTA, $10 \mu \mathrm{l} 100 \mathrm{mM} \mathrm{MgCl} 2$, and $10 \mu \mathrm{l}$ phosphatidylinositol $(2 \mu \mathrm{g} / \mu \mathrm{l})$ sonicated in $10 \mathrm{mM}$ Tris $(\mathrm{pH}$ 7.5), EDTA $1 \mathrm{mM}$. Reaction was initiated by the addition of $10 \mu \mathrm{l} 440 \mu \mathrm{M}$ ATP containing $30 \mu \mathrm{Ci}\left[\gamma-{ }^{32} \mathrm{P}\right] \mathrm{ATP}$ $(6000 \mathrm{Ci} / \mathrm{mmol})$. After $10 \mathrm{~min}$ at room temperature with constant shaking, the reaction was terminated by the addition of $20 \mu \mathrm{l} 8 \mathrm{~N} \mathrm{HCl}$ and $160 \mu \mathrm{l}$ methanolchloroform (1:1). Mixtures were centrifuged and the lower organic phase applied to silica TLC plates (Merck) coated with $1 \%(\mathrm{w} / \mathrm{v})$ potassium oxalate. TLC plates were developed in $\mathrm{CHCl}_{3}: \mathrm{CH}_{3} \mathrm{OH}: \mathrm{H}_{2} \mathrm{O}: \mathrm{NH}_{4} \mathrm{OH}$ $(60: 47: 11 \cdot 3: 2)$ and visualized by autoradiography. Phosphatidylinositol 4-phosphate, which co-migrates with 3-phosphorylated phosphatidylinositol, was used as standard. The band corresponding to phosphatidylinositol 3-phosphate was excised and its radioactivity quantitated by liquid scintillation counting.

\section{Statistical analysis}

Results are presented as means \pm S.E.M. Experiments were performed by analyzing all groups of animals in parallel. Statistical analyses were performed by ANOVA followed by the Tukey-Kramer test using the InStat statistical program by GraphPad Software, Inc. (San Diego, CA). Student's $t$ test was used when the values of two groups were analyzed. The level of significance used was $P<0 \cdot 05$.

\section{Results}

\section{Characteristics of the animals studied}

Data on body weight and plasma glucose and insulin concentrations of the studied animals are presented in 
Table 1 Characteristics of the experimental animals. Values are means \pm S.E.M.; $n=12$ per group

\begin{tabular}{lrll} 
& \multicolumn{1}{c}{ Control } & & GHR-KO \\
\cline { 2 - 2 } Body weight $(\mathrm{g})$ & $25 \pm 2$ & & $13 \pm 1^{*}$ \\
Glucose $(\mathrm{mg} / \mathrm{dl})$ & $165 \pm 8$ & & $97 \pm 2^{*}$ \\
Insulin $(\mu \mathrm{lU} / \mathrm{ml})$ & $23 \pm 6$ & $<4^{*}$ \\
\cline { 2 - 3 } & & \\
\hline
\end{tabular}

*Significantly different from the control value $(P<0 \cdot 001)$.

Table 1. The lack of GHR led to a dramatic reduction in fasting insulin plasma concentrations and to a marked decrease in glucose plasma concentrations in GHR-KO mice. Insulin concentrations in GHR-KO mice were below limit of detection of the assay (less than $4 \mu \mathrm{IU} / \mathrm{ml}$ ); glucose concentrations averaged $58 \%$ of values measured in normal animals.

\section{Insulin receptor abundance and tyrosine phosphorylation in liver}

To determine the abundance of IR in liver, homogenates of liver of the GHR-KO mice and their control littermates were subjected to immunoprecipitation using an antibody to the IR $\beta$-subunit ( $\alpha$ IR), followed by immunoblotting with the same antibody. We found a major up-regulation of insulin receptor immunoreactivity in the liver of GHR-KO mice (Fig. 1A, B). Insulin receptor levels in GHR-KO animals were increased to $180 \pm 14 \%(n=10$; $P<0 \cdot 01)$ of values measured in the normal controls.

To evaluate the tyrosine phosphorylation status of the IR, liver homogenates were obtained from control and GHR-KO mice that had been injected with saline vehicle or insulin. Extracts were subjected to immunoprecipitation with $\alpha$ IR and immunoblotted with an antiphosphotyrosine antibody $(\alpha \mathrm{PY})$. The amount of tyrosine phosphorylation of the IR $\beta$-subunit was quantitated by densitometry. Comparisons were made setting the value of insulin-stimulated controls as 100\%. Basal phosphorylation of the IR was similar for control and GHR-KO mice $(6 \pm 4$ vs $6 \pm 3 \%$ respectively; Fig. 1C, D). Insulin stimulated the tyrosine phosphorylation of the $95 \mathrm{kDa}$ $\beta$-subunit of the IR $16 \cdot 6$-fold in liver of control animals and 21.3-fold in GHR-KO mice. Thus, in the liver of GHR-KO mice, insulin-stimulated IR phosphorylation was increased by $28 \pm 7 \%(n=5 ; P<0 \cdot 01)$ compared with that in control animals (Fig. 1C, D).

Although IR abundance was increased in liver of GHR-KO mice, when the data were normalized for the amount of receptor protein in liver, the hepatic receptor phosphorylation in liver of GHR-KO mice was reduced to $71 \%$ of control values.

\section{IRS-1 abundance and tyrosine phosphorylation in liver}

To evaluate IRS-1 protein abundance, liver homogenates were subjected to immunoprecipitation with a specific
anti-IRS-1 antibody ( $\alpha$ IRS-1) followed by immunoblotting with the same antibody. In liver of GHR-KO mice, there was no statistically significant change in the abundance of IRS-1, as evaluated by scanning densitometry $(n=10$; Fig. 2A, B).

To assess the extent of IRS-1 tyrosine phosphorylation under basal conditions and after insulin administration, liver homogenates were immunoprecipitated with $\alpha$ IRS-1 and subjected to immunoblotting with $\alpha$ PY. Basal IRS-1 tyrosine phosphorylation was low in both groups of animals (11 $\pm 4 \%$ and $15 \pm 6 \%$ for control and GHR-KO mice respectively). There was a slight but not statistically significant increase in the insulin-stimulated phosphorylation of IRS-1 in liver of GHR-KO mice (121 $\pm 10 \%$ of control values; $n=5$ ).

p85 association and p85 abundance in liver

To assess p85 association with IRS-1, samples that had been immunoprecipitated with $\alpha$ IRS-1 were immunoblotted with ap85 as described in Methods. As shown in Fig. 3A, in the liver of GHR-KO mice, there was a slight increase in the amount of p85 present in $\alpha$ IRS-1 immunoprecipitates under basal conditions, but this apparent change was not statistically significant (Fig. 3 B). The association of insulin-stimulated p 85 with IRS-1 in liver of GHR-KO mice reached levels similar to those found in control mice $(n=5$; Fig. $3 \mathrm{~A}, \mathrm{~B})$.

To determine if the lack of GHR was associated with changes in the abundance of p85 in liver, liver homogenates were subjected to immunoblotting with ap85. A representative autoradiogram showing p85 protein from two control and two GHR-KO mice is shown in Fig. 3C. Densitometric analysis showed that there was no change in the abundance of $\mathrm{p} 85$ in the liver of GHR-KO mice $(n=8$; Fig. 3D).

\section{PI 3-kinase activity in liver}

A low basal PI 3-kinase activity was present in $\alpha$ IRS-1 immunoprecipitates from liver of GHR-KO and control mice (Fig. 4A, B). As the figure shows, insulin-stimulated IRS-1-associated PI 3-kinase activity in liver of GHR-KO mice did not differ significantly from that found in their control littermates $(109 \pm 7 \%$ of control values; $n=4)$. Concordant with the IRS-1-associated PI 3-kinase activity, the total phosphotyrosine-associated PI 3-kinase activity in liver of GHR-KO mice reached values that were comparable to those detected in the control group. The insulin-stimulated PI 3-kinase activity measured in $\alpha \mathrm{PY}$ immunoprecipitates from liver of GHR-KO mice was $106 \pm 9 \%$ of control values $(n=4$; Fig. 4C, D).

\section{She abundance and tyrosine phosphorylation in liver}

To evaluate Shc protein abundance, liver homogenates were subjected to immunoprecipitation with a specific 


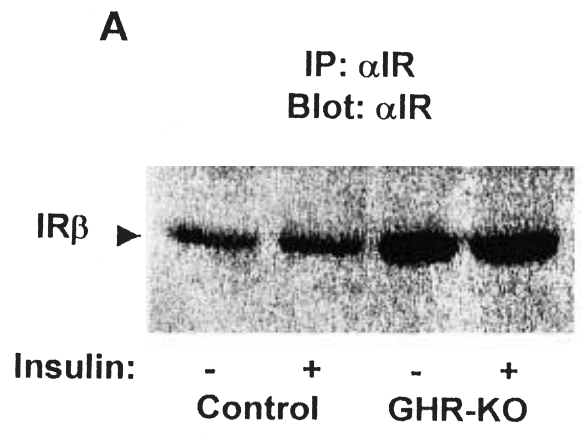

C

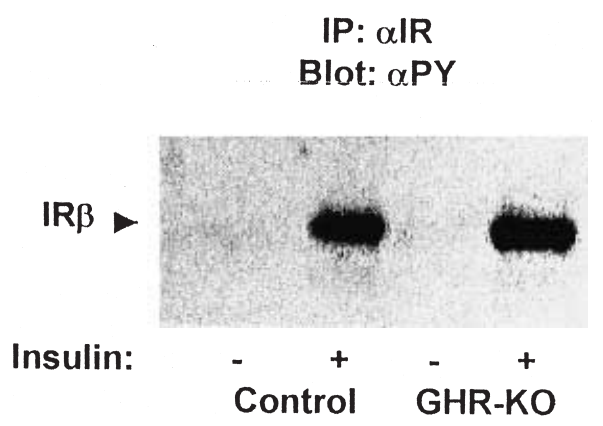

B

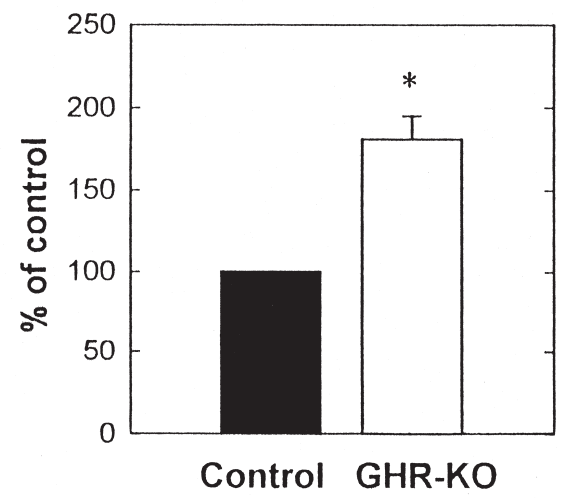

D

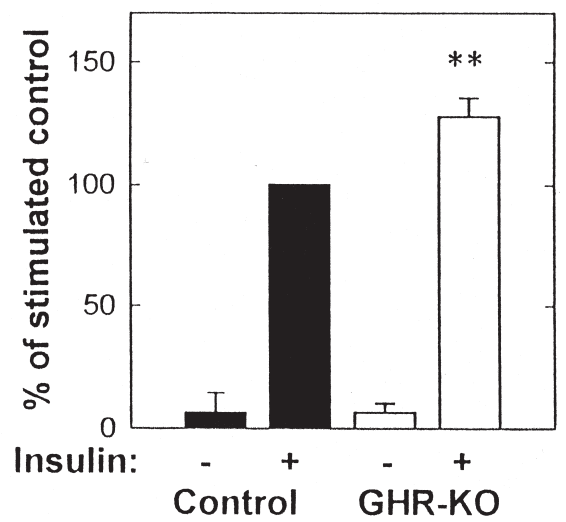

Figure 1 Insulin receptor (IR) abundance and tyrosine phosphorylation in liver of GHR-KO and control mice. Animals were anesthetized, and normal saline $(-)$ or insulin $(10 \mathrm{IU} / \mathrm{kg})(+)$ was injected into the portal vein. After $50 \mathrm{~s}$, liver was excised and tissue extraction was performed as described in Materials and Methods. Equal amounts of solubilized liver protein $(8 \mathrm{mg})$ were immunoprecipitated (IP) with an anti-IR $\beta$-subunit antibody $(\alpha \mid \mathrm{R})$, separated by SDS-PAGE, and subjected to immunoblot analysis with the same antibody (A). (B) Data quantification by scanning densitometry: means \pm S.E.M. of five separate experiments ( $n=10$ /group), expressed as relative to control values, which were set at $100 \%$. ${ }^{*} P<0.01$ compared with control mice. (C) The same samples were immunoprecipitated with $\alpha$ IR and immunoblotted with anti-phosphotyrosine antibody PY99 ( $\alpha$ PY) as described in Materials and Methods. (D) Quantification of IR tyrosine phosphorylation by scanning densitometry: means \pm S.E.M. of five different experiments ( $n=5$ /group), expressed as relative to control, assigning a value of $100 \%$ to the insulin-stimulated control mean. ${ }^{*} P<0 \cdot 01$ compared with insulin-stimulated control mice.

antibody that recognizes the 46-, 52- and 66-kDa isoforms of Shc ( $\alpha$ Shc), followed by immunoblotting with the same antibody. The predominant bands detected corresponded to the 46- and $52-\mathrm{kDa}$ isoform of $\mathrm{Shc}$, whereas the 66-kDa isoform was barely detected (Fig. 5A). In liver of GHR-KO mice, there was no statistically significant change in the abundance of p46 and p52 isoforms of Shc, as evaluated by scanning densitometry $(n=6$; Fig. $5 \mathrm{~A}, \mathrm{~B})$.

To assess the extent of Shc tyrosine phosphorylation under basal conditions and after insulin administration, liver homogenates were immunoprecipitated with $\alpha$ Shc and subjected to immunoblotting with $\alpha \mathrm{PY}$. Consistent with previous reports (Paez-Espinosa et al. 1998), we found no detectable phosphorylation in the p46 and p66 isoforms of Shc (Fig. 5C). Basal tyrosine phosphorylation of the $52-\mathrm{kDa}$ isoform of Shc was relatively high in both groups of animals ( $35 \pm 6 \%$ and $43 \pm 6 \%$ for control and GHR-KO mice respectively). Consistent with the phosphorylation of IRS-1, there was a slight but not statistically significant increase in the insulin-stimulated 
A

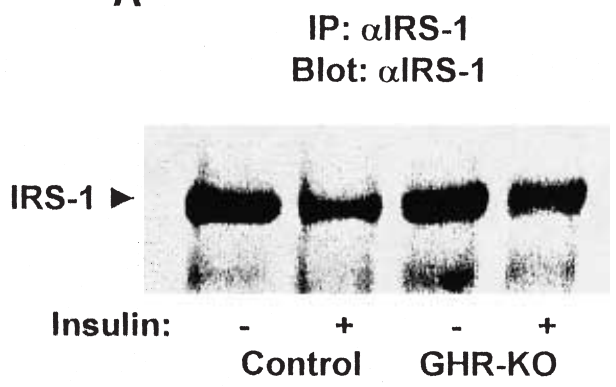

C

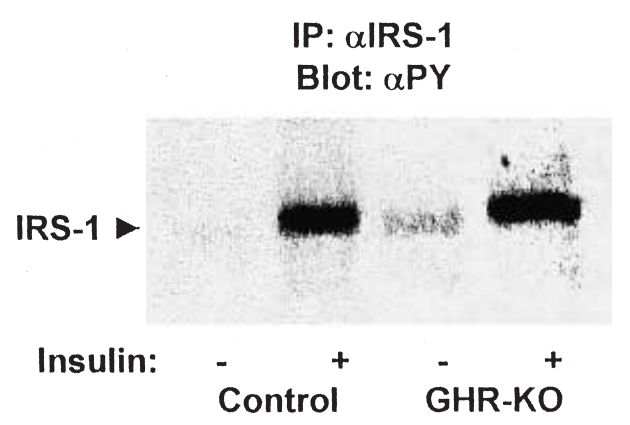

B

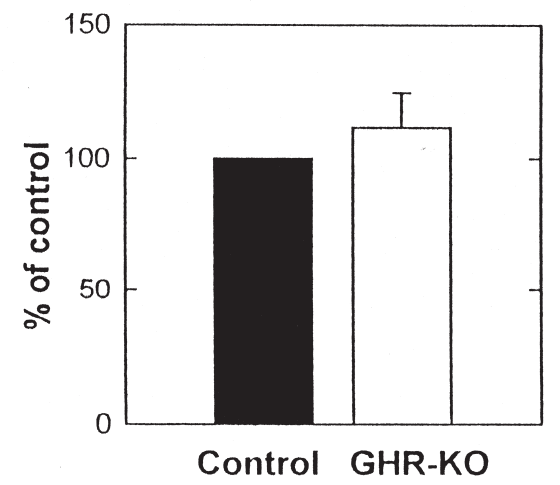

D

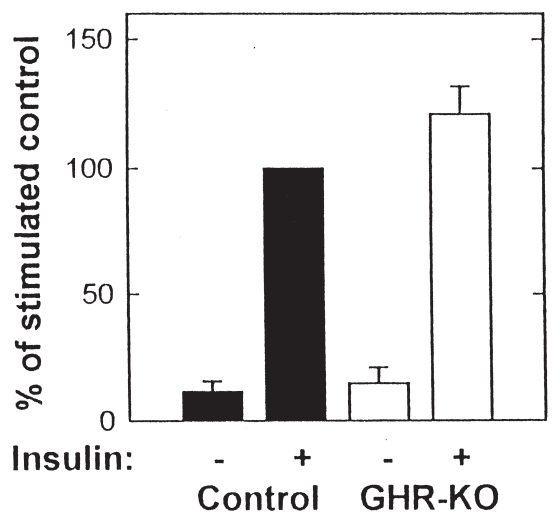

Figure 2 IRS-1 abundance and tyrosine phosphorylation in liver of GHR-KO and control mice. Animals were anesthetized, and normal saline $(-)$ or insulin $(10 \mathrm{IU} / \mathrm{kg})(+)$ was injected into the portal vein. After $50 \mathrm{~s}$, liver was excised and tissue extraction was performed as described in Materials and Methods. Equal amounts of solubilized liver protein $(8 \mathrm{mg}$ ) were immunoprecipitated (IP) with an anti-IRS-1 antibody (aIRS-1), separated by SDS-PAGE, and subjected to immunoblot analysis with the same antibody (A). (B) Data quantification by scanning densitometry: means \pm S.E.M. of five separate experiments ( $n=10 /$ group), expressed as relative to control values, which were set at $100 \%$. (C) The same samples were immunoprecipitated with $\alpha$ IRS-1 and immunoblotted with anti-phosphotyrosine antibody PY99 ( $\alpha$ PY) as described in Materials and Methods. (D) Quantification of IRS-1 tyrosine phosphorylation by scanning densitometry: means \pm S.E.M. of five different experiments ( $n=5 /$ group), expressed as relative to control, assigning a value of $100 \%$ to the insulin-stimulated control mean.

phosphorylation of Shc in liver of GHR-KO mice $(124 \pm 15 \%$ of control values; $n=3)$ (Fig. 5 C, D).

\section{Discussion}

GHR-KO mice exhibit a pronounced decrease in fasting insulin concentrations and a moderate decrease in fasting glucose concentrations. This indicates that lack of GHR induces a state of insulin hypersensitivity, with glucose homeostasis being preserved with little circulating insulin.
Association of GH deficiency with hypersensitivity to insulin has long been recognized in humans and animals (Davidson 1987). In GH-deficient patients there is a tendency to hypoglycemia (Hopwood et al. 1975), apparently mainly caused by reduced hepatic glucose output (Bougneres et al. 1985). GH deficiency in rats also leads to increased insulin sensitivity (Daugaard et al. 1999). As demonstrated in insulin tolerance tests, the sensitivity to insulin is indeed enhanced in GHR-KO mice (Coschigano et al. 1999). When an intraperitoneal injection of insulin $(0.75 \mathrm{IU} / \mathrm{kg})$ is given, blood glucose 
A
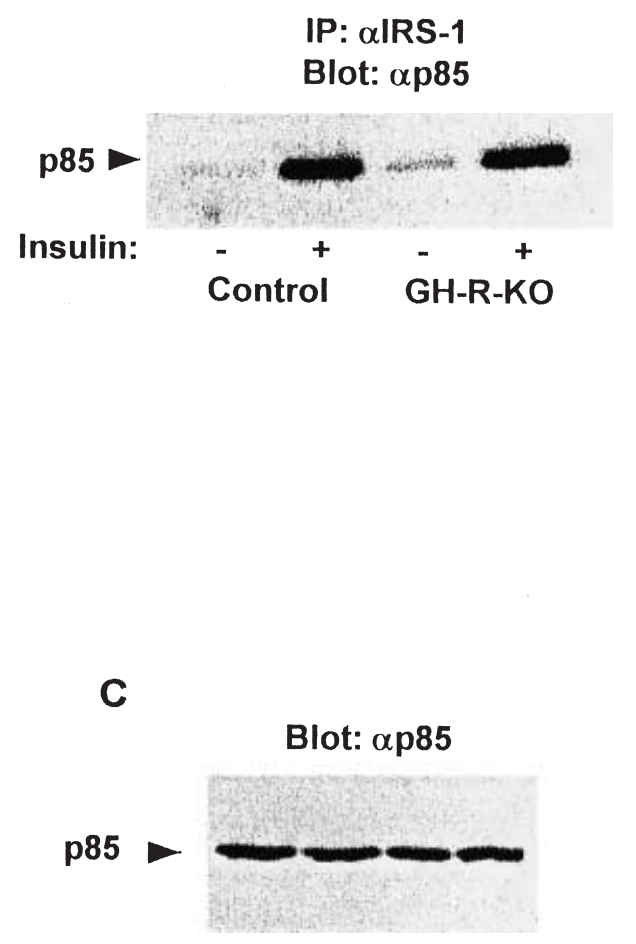

Control GH-R-KO
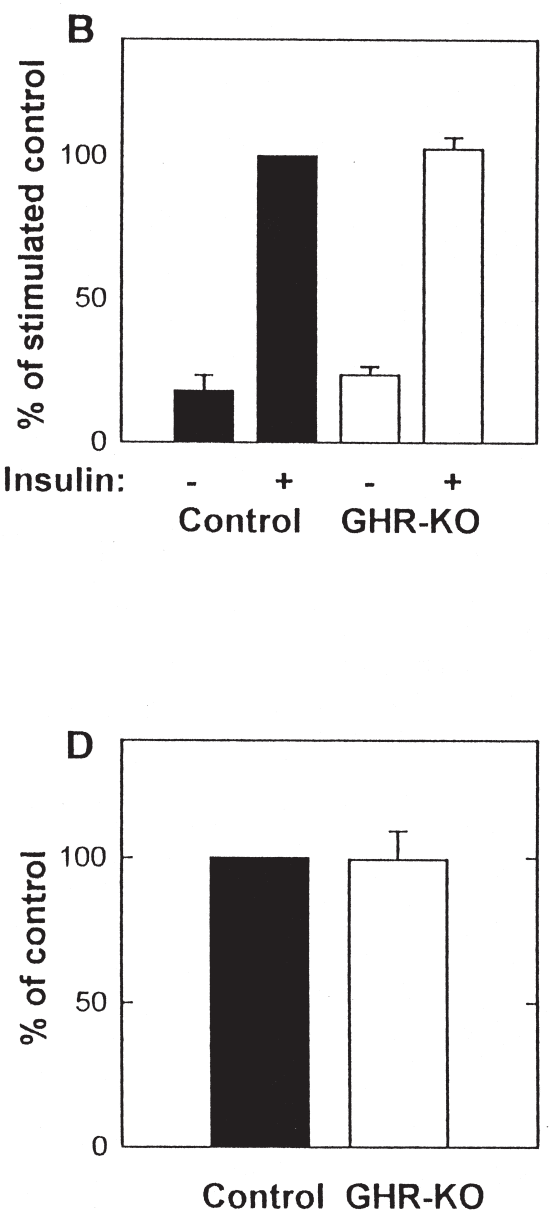

Figure 3 Association of IRS-1 with p85 and p85 abundance in liver of GHR-KO and control mice. Animals were injected as described in Figs 1 and 2. Equal amounts of liver protein were subjected to immunoprecipitation with $\alpha$ IRS-1, separated by SDS-PAGE, and subjected to immunoblot analysis with an antibody to the p85 subunit of PI 3-kinase (ap85) (A). (B) Scanning densitometry on autoradiograms from five separate experiments ( $n=5 /$ group): means \pm S.E.M. expressed as relative to control, assigning a value of $100 \%$ to the insulin-stimulated control mean. (C) Aliquots from total liver extracts containing equal amounts of protein $(120 \mu \mathrm{g})$ separated by SDS-PAGE and immunoblotted with $\alpha p 85$ as described in Materials and Methods. (D) Quantification of p85 abundance by scanning densitometry: means \pm S.E.M. of four separate experiments ( $n=8 /$ per group).

concentrations decrease significantly more steeply in fasted GHR-KO mice than in controls (Coschigano et al. 1999). Moreover, preliminary observations suggest that this finding may be of physiological relevance as, in the fed state, glucose plasma concentrations are significantly lower in GHR-KO mice than in control animals (F P Dominici et al., unpublished data).

In addition, GHR-KO mice display impaired tolerance to glucose, as determined in glucose tolerance tests. Insulin sensitivity assays suggest that the glucose intolerance is not the result of a reduced tissue sensitivity to insulin. Insulin requirements in terms of glucose homeostasis are dramatically reduced in GHR-KO mice. Thus, in these animals, $\beta$-cell function might be reduced, reflecting an adaptative response to the extremely low need for insulin. The impaired handling of a glucose load may thus, presumably, reflect reduced synthesis or release of insulin (Coschigano et al. 1999). Because of these characteristics, GHR-KO mice have a role as a very useful animal model in which to study how the absence of GHR-mediated biological effects of $\mathrm{GH}$ influences the insulin signaling pathway. Thus, in the present study we have examined the status of the first steps of the insulin signaling system in liver of GHR-KO in vivo. We have previously analyzed insulin signal transduction in liver of transgenic mice overexpressing bovine $\mathrm{GH}$, and showed that this is a suitable tissue in which to study $\mathrm{GH}$ and insulin interactions in vivo (Dominici et al. 1999b). 
A

\section{Precipitating antibody: $\alpha$ IRS-1}

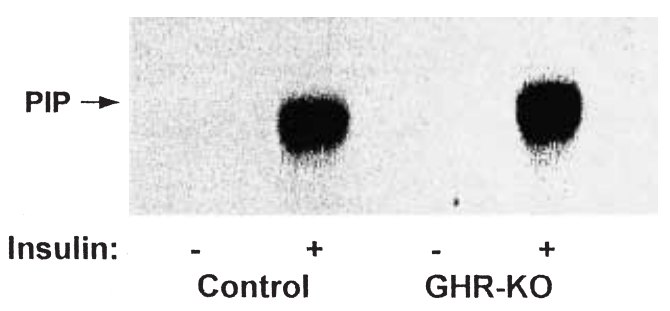

C

Precipitating antibody: $\alpha \mathrm{PY}$

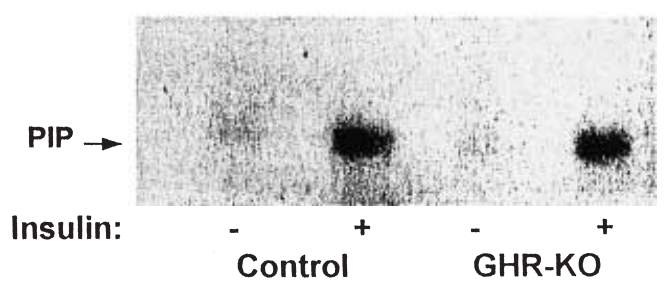

B

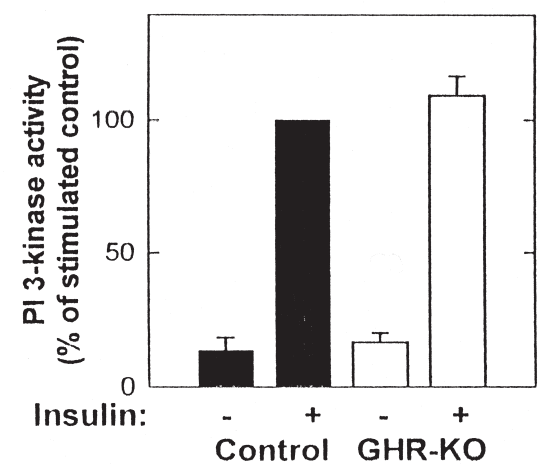

D

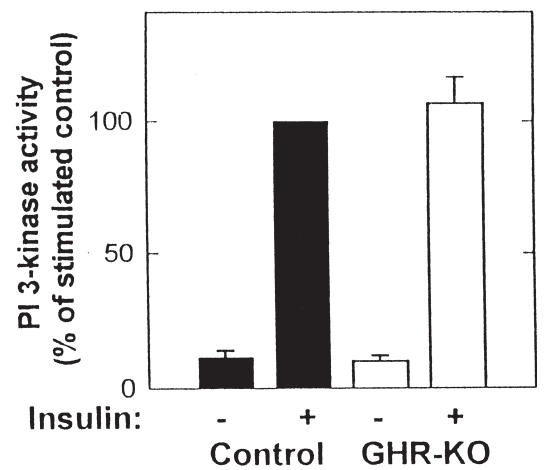

Figure 4 IRS-1-, and phosphotyrosine-associated PI 3-kinase activities in liver of GHR-KO and control mice. Animals were injected with insulin $(10 \mathrm{IU} / \mathrm{kg})(+)$ or its diluent $(-)$ in the portal vein. Equal amounts of liver proteins $(8 \mathrm{mg})$, isolated as described in Materials and Methods were incubated with $\alpha$ IRS-1 (A) or with $\alpha \mathrm{PY}(\mathrm{C})$ and protein A-Sepharose. PI 3-kinase was determined in immunoprecipitates in presence of phosphatidylinositol and $\left[\gamma_{-}{ }^{32} \mathrm{P}\right]$ ATP as described in Materials and Methods. Lipid products were separated by thin-layer chromatography ( $\mathrm{A}$ and $\mathrm{C})$. (B, D) The radioactivity present in spots that co-migrated with a PI 4-phosphate (PIP) standard was quantified by liquid scintillation. Values are expressed as relative to control, assigning a value of $100 \%$ to the insulin-stimulated control mean. Data shown in (B) and (D) are means \pm S.E.M. of four separate experiments in each case ( $n=4 /$ group).

The abundance of IR in liver of GHR-KO, as measured by immunoblotting, was markedly increased. This up-regulation could be a long-term consequence of the very low plasma concentrations of insulin observed in GHR-KO mice. A negative relationship between insulin concentrations and the number of IRs has been demonstrated both in vivo (Kahn et al. 1978, Vigneri et al. 1978, Almira \& Reddy 1979) and in vitro (Gavin et al. 1974). Chronic hypoinsulinemic states induced by streptozotocin (STZ) administration, prolonged fasting or hypophysectomy in rodents, are known to produce an increase in the number of IRs in liver (Kahn et al. 1978, Vigneri et al. 1978, Almira \& Reddy 1979). Moreover, although GH concentrations are increased in GHR-KO mice, it is highly unlikely that the increase in this hormone could directly increase the levels of IR in liver. Studies in vitro
(Lesniak \& Roth 1976, Maloff et al. 1980) and in vivo (Dominici et al. 1998) have demonstrated that GH does not directly affect IR concentration and absence of GHR probably precludes any actions of GH. Transgenic mice overexpressing $\mathrm{GH}$ exhibit reduced insulin binding to liver membranes as well as reduced IR protein abundance in liver (Balbis et al. 1996, Dominici et al. 1998). We have demonstrated that this reduction in GH-transgenic mice is the result of an increase in plasma concentrations of insulin, and that $\mathrm{GH}$, despite being present in large amounts, does not influence the IR levels in liver (Dominici et al. 1998).

Our data showed a significant $(28 \%)$ increase in the insulin-dependent phosphorylation of the IR in liver of GHR-KO mice. However, insulin-stimulated IRS-1 phosphorylation levels in liver of GHR-KO mice were 


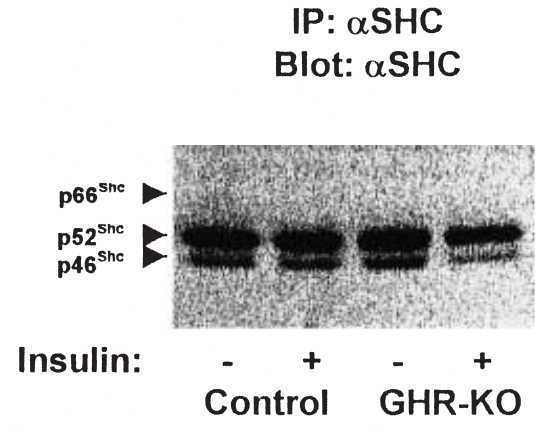

IP: $\alpha$ SHC

Blot: $\alpha$ SHC
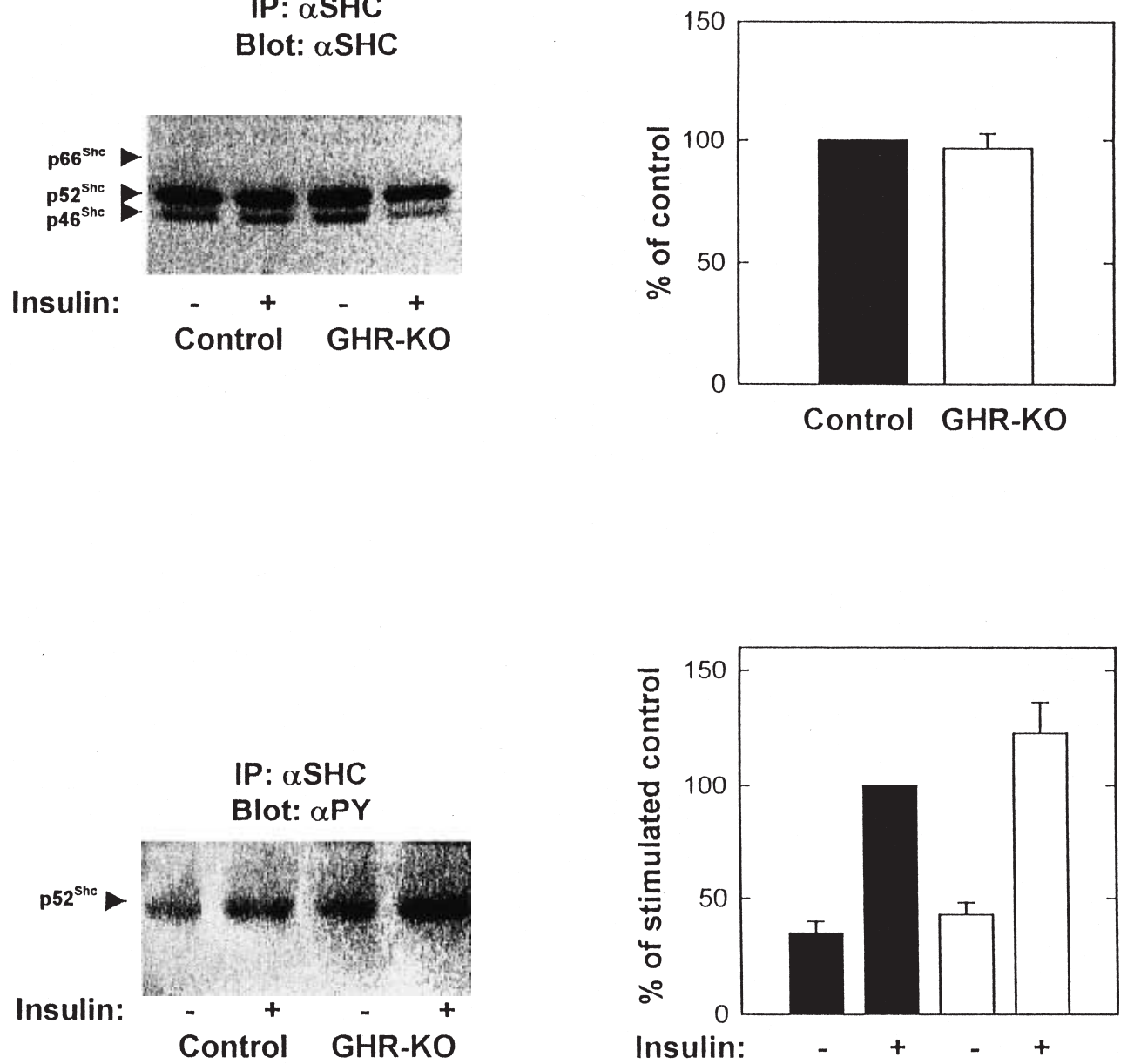

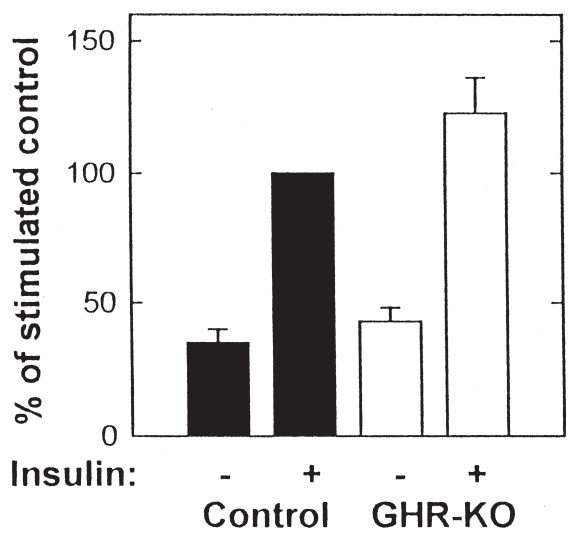

Control GHR-KO

Figure 5 Shc abundance and tyrosine phosphorylation in liver of GHR-KO and control mice. Animals were anesthetized, and normal saline $(-)$ or insulin $(10 \mathrm{lU} / \mathrm{kg})(+)$ was injected into the portal vein. After $50 \mathrm{~s}$, liver was excised and tissue extraction was performed as described in Materials and Methods. Equal amounts of solubilized liver protein $(8 \mathrm{mg})$ were immunoprecipitated (IP) with an anti-Shc antibody ( $\alpha$ Shc), separated by SDS-PAGE, and subjected to immunoblot analysis with the same antibody (A). (B) Data quantification by scanning densitometry: means \pm S.E.M. of three separate experiments ( $n=6 /$ group), expressed as relative to control values, which were set at $100 \%$. (C) The same samples were immunoprecipitated with $\alpha$ Shc and immunoblotted with anti-phosphotyrosine antibody PY99 ( $\alpha$ PY) as described in Materials and Methods. (D) Quantification of Shc tyrosine phosphorylation by scanning densitometry: means \pm S.E.M. of three different experiments ( $n=3 /$ group), expressed as relative to control, assigning a value of $100 \%$ to the insulin-stimulated control mean.

comparable to those found in normal mice, which suggest that the ability of the IR to use IRS-1 as a substrate is intact in these animals. Similar findings were reported in rats that had been exposed to a 72-h fast, a condition in which, similar to the findings in GHR-KO mice, both insulin and glucose concentrations are less than normal (Saad et al. 1992).

Our finding that basal phosphorylation of IRS-1 was normal, with a tendency to be increased, in liver of GHR-KO mice was unexpected. GH has been shown to induce the tyrosine phosphorylation of IRS-1 in liver of rats in vivo (Yamauchi et al. 1998, Thirone et al. 1999). Basal IRS-1 tyrosine phosphorylation is greatly increased in liver of transgenic mice overexpressing GH (Dominici et al. 1999b). Chronic administration of GH also leads to an increase in the basal tyrosine phosphorylation of IRS-1 in liver of intact rats (Thirone et al. 1996). On the basis of these findings, we expected that the absence of $\mathrm{GH}$ activity would lead to a reduced tyrosine phosphorylation of IRS-1 under basal conditions. However, it was recently shown that prolactin (PRL) is also able to promote the tyrosine phosphorylation of IRS-1, both in 293-PRL 
receptor cells (Berlanga et al. 1997) and in liver of intact rats (Yamauchi et al. 1998). We have recently demonstrated that circulating PRL concentrations are increased almost threefold in GHR-KO mice (Bartke et al. 1999, Chandrashekar et al. 1999), and thus it is possible to speculate that our current results may be the consequence of the interaction of PRL with IRS-1 through the PRL receptor.

Some contradictory observations have been reported when the relationship between insulin and IRS-1 concentrations in liver in vivo was analyzed using various rodent models (Saad et al. 1992). IRS-1 protein concentrations were reported to be moderately increased in liver of STZ-treated rats, in which insulin is virtually absent (Saad et al. 1992). Conversely, hyperinsulinemic ob/ob mice showed reduced IRS-1 protein concentrations in liver (Saad et al. 1992), which led the authors to suggest that IRS-1 concentrations are inversely related to insulin concentrations in vivo. However, in the same work it was found that in rats made hypoinsulinemic by a 72-h fast, liver IRS-1 concentrations were not significantly different from those in control rats (Saad et al. 1992).

In the present study, we found that IRS-1 protein abundance was unchanged in liver of hypoinsulinemic GHR-KO mice compared with that in normal mice. This is in excellent agreement with our recent demonstration that $\mathrm{GH}$-transgenic mice display normal concentrations of IRS-1 in liver despite being hyperinsulinemic (Dominici et al. 1999b). Together with the present results, those observations indicate that insulin may not be the only factor involved in the regulation of IRS-1 protein expression in vivo. Other factors, such as changes in the concentrations of glucose or counterregulatory hormones, might also be involved in this regulation.

Insulin-stimulated tyrosine phosphorylation of IRS-1 results in an intracellular signaling step (which involves the docking of the $\mathrm{p} 85$ subunit of PI 3-kinase) that parallels the increase in tyrosine phosphorylation of IRS-1. This association results in the activation of PI 3-kinase (Backer et al. 1992, Lavan et al. 1992). It is becoming apparent that PI 3-kinase plays a central role in signal-transduction pathways linking insulin with many of its specific endpoint cellular responses (Shepherd et al. 1998). One of the mechanisms by which insulin regulates glucose homeostasis is by controlling hepatic glucose output; attenuation of glucose-6-phosphatase activity is one of the processes involved, and PI 3-kinase has recently been shown to mediate this attenuation (Mithieux et al. 1998). Thus activation of PI 3-kinase represents a principal step in the pathway of insulin action in the liver. Therefore, to characterize the consequences of the lack of GH effects on the insulin signaling cascade further, we have measured the association of IRS-1 with p85 and the PI 3-kinase activity in liver of GHR-KO mice.

Consistent with the tyrosine phosphorylation of IRS-1, both the basal and insulin-stimulated association of $\mathrm{p} 85$ with IRS-1 in liver of GHR-KO mice showed normal values. Moreover, whereas basal IRS-1-associated PI 3-kinase activity was found to be slightly but not statistically significantly increased, insulin-stimulated IRS-1associated activity was found to be unaltered in liver of GHR-KO mice. However, in IRS-1-deficient mice it was demonstrated that insulin may use other signaling molecules such as IRS-2 to activate PI 3-kinase (Araki et al. 1994, Tamemoto et al. 1994). Therefore, in the present study we also measured the total phosphotyrosineassociated PI 3-kinase in liver of GHR-KO mice. As was found for the IRS-1-associated PI 3-kinase activity, insulin stimulated the total phosphotyrosine-associated PI 3kinase activity to a similar extent in liver of both control and GHR-KO mice. Taken together, our results suggest that the signaling pathway leading to activation of PI 3 -kinase by insulin is not altered in the liver of GHR-KO mice.

The transforming protein Shc is also tyrosine phosphorylated by the IR in response to insulin stimulation (White et al. 1997). Although it was shown that insulin is capable of activating the MAP kinase cascade through IRS-1, various reports indicate that She has a dominant role in this activation (Sasaoka et al. 1994, Yamauchi $\mathcal{E}$ Pessin 1994, White 1997). Therefore, to have a more detailed indication of the status of insulin signaling in liver of GHR-KO mice, in the present work we also evaluated the tyrosine phosphorylation of Shc in liver of these mice. Consistent with data on IRS-1, both the abundance and phosphorylation of Shc were found to be unaltered in these animals. Therefore, as Shc and IRS-1 constitute major pathways by which insulin leads to activation of the MAP kinase cascade (Sasaoka et al. 1994, Yamauchi \& Pessin 1994, White 1997), and in view of our present results showing a non-significant increase in the tyrosine phosphorylation of either of these proteins in liver of GHR-KO mice, it seems reasonable to think that there should be no significant alteration in the activity of MAP kinase in the liver of these animals.

We detected a large increase in the abundance of IR in liver, which most probably reflected receptor up-regulation due to hypoinsulinemia, together with an increase in the insulin-stimulated phosphorylation of the IR in this tissue. In contrast, the post-receptor steps analyzed - namely IRS-1 phosphorylation, Shc phosphorylation, p85-IRS-1 association and the activity of PI 3-kinase associated with IRS-1 and phosphotyrosine showed values comparable to those found in normal mice. Interestingly, the changes detected on insulin signal transduction in liver of GHR-KO mice are close to being the opposite of those we recently found in liver of transgenic mice overexpressing GH (Dominici et al. 1999b). Exposure to chronic GH excess leads to hyperinsulinemia, which in turn produces a down-regulation of the IR in liver. Moreover, we detected that the basal tyrosine phosphorylation of the IR, the tyrosine phosphorylation of 
the IRS-1, its association with the p85 subunit of PI 3-kinase, and the phosphotyrosine-associated activity of PI 3-kinase in GH transgenic mice are maximal in the basal state (Dominici et al. 19996).

It appears that the increase in hepatic IR protein concentrations and phosphorylation in GHR-KO mice is sufficient to compensate for reduced insulin signaling in this tissue. Thus the liver of GHR-KO mice is adapted to function in the presence of low concentrations of insulin. We believe that results from the present study support the notion that the concentration and state of phosphorylation of the IR have critical roles in the intracellular signal transduction that leads to the biological actions of insulin on the metabolism (Wilden \& Kahn 1994, Patti \& Kahn 1998). Therefore, compensatory changes in the IR abundance and tyrosine kinase activity may be sufficient to maintain glucose homeostasis in the presence of a wide range of insulin concentrations.

In summary, we have analyzed the early steps of insulin signaling in liver of GHR-KO mice and found that the abundance of IR in this tissue is increased almost twofold. The in vivo insulin-stimulated tyrosine phosphorylation of the IR is increased also. However, in spite of these changes, the subsequent steps of the insulin signaling pathway, namely the insulin-induced tyrosine phosphorylation of Shc and IRS-1, the association of IRS-1 with p85, and the total phosphotyrosine- and IRS-1associated PI 3-kinase activity are unaltered. These changes may reflect an adaptation to very low circulating concentrations of insulin and could account at least in part for the increased insulin sensitivity displayed by these animals.

\section{Acknowledgements}

Daniel Turyn is a Career Investigator from Consejo Nacional de Investigaciones Científicas y Tecnológicas of Argentina (CONICET) and received grant support from the University of Buenos Aires, CONICET, and Agencia Nacional de Promoción Científica y Tecnológica. Support for these studies was also provided by National Institute of Child Health and Human Development Grant HD-20001 (A B). J J Kopchick is supported in part by the State of Ohio's Eminent Scholars Program, which includes a gift from Milton and Lawrence Goll and by Sensus Corp.

\section{References}

Almira EC \& Reddy WJ 1979 Effect of fasting on insulin binding to hepatocytes and liver plasma membranes from rats. Endocrinology 104 205-211.

Araki E, Lipes MA, Patti MA, Bruning JC, Haag B, Johnson RS \& Kahn CR 1994 Alternative pathway of insulin signaling in mice with target disruption of the IRS-1 gene. Nature 372 186-190.
Argetsinger LS, Campbell GS, Yang X, Witthuhn BA, Silvennoinen O, Ihle JN \& Carter-Su C 1993 Identification of JAK2 as as growth hormone receptor-associated tyrosine kinase. Cell $\mathbf{7 4}$ 237-244.

Argetsinger LS, HSU GW, Myers MG Jr, Billestrup N, White MF \& Carter-Su C 1995 Growth hormone, interferon-gamma, and leukemia inhibitory factor promoted tyrosyl phosphorylation of insulin receptor substrate-1. Journal of Biological Chemistry 270 14685-14692.

Backer JM, Myers MG Jr, Shoelson SE, Chin DJ, Sun XJ, Miralpeix M, Hu P, Margolis B, Skolnik EY, Schlessinger J \& White MF 1992 Phosphatidylinositol 3'-kinase is activated by association with IRS-1 during insulin stimulation. EMBO Journal 11 3469-3479.

Balbis A, Bartke A \& Turyn D 1996 Overexpression of bovine growth hormone in transgenic mice is associated with changes in hepatic insulin receptors and in their kinase activity. Life Sciences $\mathbf{5 9}$ 1363-1371.

Bartke A, Chandrashekar V, Turyn D, Steger RW, Debeljuk L, Winters TA, Mattison JA, Danilovich NA, Croson W, Wernsing DR \& Kopchick JJ 1999 Effects of growth hormone overexpression and growth hormone resistance on neuroendocrine and reproductive functions in transgenic and knock-out mice. Proceedings of the Society for Experimental Biology and Medicine 222 113-123.

Berlanga JJ, Gualillo O, Buteau H, Applanat M, Kelly PA \& Edery M 1997 Prolactin activates tyrosyl phosphorylation of insulin receptor substrate 1 and phosphatidylinositol 3-OH kinase. Journal of Biological Chemistry 272 2050-2052.

Bougneres P-F, Artavia-Loria E, Ferre P, Chaussain J-L \& Job L-C 1985 Effect of hypopituitarism and growth hormone replacement therapy on the production and utilization of glucose in childhood. Journal of Clinical Endocrinology and Metabolism 61 1152-1157.

Bradford MM 1976 A rapid and sensitive method for the quantitation of microgram quantities of protein utilizing the principle of protein-dye binding. Analytical Biochemistry 72 248-254.

Bratusch-Marrain PR, Smith D \& DeFronzo RA 1982 The effect of growth hormone on glucose metabolism and insulin secretion in man. Journal of Clinical Endocrinology and Metabolism 55 973-982.

Chandrashekar V, Bartke A, Coshigano KT \& Kopchick JJ 1999 Pituitary and testicular function in growth hormone receptor gene knockout mice. Endocrinology 140 1082-1088.

Cheatham B \& Kahn CR 1995 Insulin action and the insulin signaling network. Endocrine Reviews 16 117-142.

Coschigano KT, Riders ME, Bellush LL \& Kopchick JJ 1999 Glucose metabolism in growth hormone receptor/binding protein gene disrupted mice. 81st Annual Meeting of the Endocrine Society, San Diego, CA, USA, 1999 (Abstract P3-537), p 553.

Daugaard JR, Lausten JL, Hanten BS \& Richter EA 1999 Insulin action in growth hormone-deficient and age-matched control rats: effect of growth hormone treatment. Journal of Endocrinology 160 $127-135$.

Davidson MB 1987 Effect of growth hormone on carbohydrate and lipid metabolism. Endocrine Reviews 8 115-131.

Dominici FP, Balbis A, Bartke A \& Turyn D 1998 Role of hyperinsulinemia on hepatic insulin receptor concentration and autophosphorylation in the presence of high growth hormone levels in transgenic mice overexpressing GH gene. Journal of Endocrinology 159 15-25.

Dominici FP, Cifone D, Bartke A \& Turyn D 1999a Alterations in early steps of the insulin-signaling system in skeletal muscle of GH-transgenic mice. American Journal of Physiology 277 E447-E454.

Dominici FP, Cifone D, Bartke A \& Turyn D 1999 boss of sensitivity to insulin at early events of the insulin signaling pathway in the liver of growth hormone-transgenic mice. Journal of Endocrinology 161 383-392.

Gavin JR III, Roth J, Neville DM Jr, De Meyts P \& Buell DN 1974 Insulin-dependent regulation of insulin receptor concentrations: a direct demonstration in cell culture. PNAS 71 84-88. 
Hopwood NJ, Forsman PJ, Kenny FM \& Drash AL 1975

Hypoglycemia in hypopituitary children. American Journal of Disabled Children 129 918-929.

Kahn CR, Goldfine ID, Neville DM Jr \& De Meyts P 1978 Alterations in insulin binding induced by changes in vivo in the levels of glucocorticoids and growth hormone. Endocrinology 103 1054-1065.

Kasuga M, Karlsson FA \& Kahn CR 1982 Insulin stimulates the phosphorylation of the 95000 dalton subunit of its own receptor. Science 215 185-187.

Lavan BE, Kuhne MR, Garner CW, Anderson D, Reedijk M, Pawson T \& Lienhard GE 1992 The association of insulin-elicited phosphotyrosine proteins with src homology 2 domains. Journal of Biological Chemistry 267 11631-11636.

Lesniak MA \& Roth J 1976 Regulation of receptor concentration by homologous hormone in IM-9 lymphocytes. Journal of Biological Chemistry 251 3720-3729.

Maloff BL, Levine JH \& Lockwood DH 1980 Direct effects of growth hormone on insulin action in rat adipose tissue maintained in vitro. Endocrinology 107 538-544.

Mithieux G, Daniele N, Payrastre B \& Zitoun C 1998 Liver microsomal glucose-6-phosphatase is competitively inhibited by the lipid products of phosphatidylinositol 3-kinase. Journal of Biological Chemistry 273 17-19.

Paez-Espinosa V, Carvalho CRO, Rojas-Alvarez F, Janeri L, Velloso LA, Boschero AC \& Saad MJA 1998 Insulin induces tyrosine phosphorylation of Shc and stimulates Shc/Grb2 association in insulin-sensitive tissues of the intact rat. Endocrine 8 193-200.

Patti ME \& Kahn CR 1998 The insulin receptor: a critical link in glucose homeostasis and insulin action. Journal of Basic and Clinical Physiology and Pharmacology 9 89-109.

Ridderstråle M, Degerman E \& Tornqvist H 1995 Growth hormone stimulates the tyrosine phosphorylation of the insulin receptor substrate-1 and its association with phosphatidylinositol 3-kinase in primary adipocytes. Journal of Biological Chemistry 270 3471-3474.

Rizza RA, Mandarino LJ \& Gerich JE 1982 Effects of growth hormone on insulin action in man. Mechanisms of insulin resistance, impaired suppression of glucose production, and impaired stimulation of glucose utilization. Diabetes 31 663-669.

Saad MJA, Araki E, Miralpeix M, Rothemberg PL, White MF \& Kahn CR 1992 Regulation of insulin receptor substrate-1 in liver and muscle of animal models of insulin resistance. Journal of Clinical Investigation 90 1839-1849.

Sasaoka T, Draznin B, Leitner JW, Langlois WJ \& JM Olefsky 1994 Shc is the predominant signaling molecule coupling insulin receptors to activation of guanine nucleotide releasing factor and p21 ras-GTP formation. Journal of Biological Chemistry 269 10734-10738.

Shepherd PR, Withers DJ \& Siddle K 1998 Phosphoinositide 3-kinase: the key switch mechanism in insulin signalling. Biochemical Journal 333 471-490.

Souza SC, Frick PG, Yip R, Lobo RB, Tai LR \& Goodman HM 1994 Growth hormone stimulates tyrosine phosphorylation of insulin receptor substrate-1. Journal of Biological Chemistry 269 30085-30088.

Sun XJ, Rothemberg P, Kahn CR, Backer JM, Araki E, Wilden P, Cahill DA, Goldstein BJ \& White MF 1991 Structure of the insulin receptor substrate IRS-1 defines a unique signal transduction protein. Nature 352 73-77.

Tamemoto H, Kadowaki T, Tobe K, Yagi T, Sakura H, Hayakawa T, Terauchi Y, Ueki k, Kaburagi Y, Satoh S, Sekchara H, Yoshioka S, Horikoshi H, Furuta Y, Ikawa Y, Kasuga M, Yazaki Y \& Aizawa S 1994 Insulin resistance and growth retardation in mice lacking insulin receptor substrate-1. Nature 372 182-186.

Thirone ACP, Carvalho CRO, Brenelli SL, Velloso LA \& Saad MJA 1996 Effect of chronic growth hormone treatment on insulin signal transduction in rat tissues. Molecular and Cellular Endocrinology 130 33-42.

Thirone ACP, Carvalho CRO \& Saad MJA 1999 Growth hormone stimulates the tyrosine kinase activity of JAK2 and induces tyrosine phosphorylation of insulin receptor substrates and SHC in rat tissues. Endocrinology 140 55-62.

Thomas MJ 1998 The molecular basis of growth hormone action. Growth Hormone and IGF Research 8 3-11.

Vigneri R, Pliam NB, Cohen DC, Pezzino V, Wong KY \& Goldfine ID 1978 in vivo regulation of cell surface and intracellular insulin binding sites by insulin. Journal of Biological Chemistry 253 8192-8197.

White MF 1997 The insulin signalling system and the IRS proteins. Diabetologia 40 S2-S17.

Wilden PA \& Kahn CR 1994 The level of insulin receptor tyrosine kinase activity modulates the activities of phosphatidylinositol 3-kinase, microtubule-associated protein, and S6 kinases. Molecular Endocrinology 8 558-567.

Yamauchi K \& Pessin JE 1994 Insulin receptor substrate-1 (IRS-1) and Shc compete for a limited pool of Grb2 in mediating insulin downstream signaling. Journal of Biological Chemistry 269 31107-31114.

Yamauchi T, Kaburagi Y, Ueki K, Tsuji Y, Stark GR, Kerr IM, Tsushima T, Akanuma Y, Komuro I, Tobe K, Yazaki Y \& Kadowaki T 1998 Growth hormone and prolactin stimulate tyrosine phosphorylation of insulin receptor substrate-1, -2 and -3 , their association with p85 phosphatidylinositol 3-kinase (PI3-kinase) and concomitantly PI3-kinase activation via JAK2 kinase. Journal of Biological Chemistry 273 15719-15726.

Zhou Y, Xu BC, Maheswari HG, He L, Reed M, Lozykowski M, Okada S, Cataldo L, Coschigamo K, Wagner TE, Baumann G \& Kopchick JJ 1997 A mammalian model for Laron syndrome produced by targeted disruption of the mouse growth hormone receptor/binding protein gene (the Laron mouse). PNAS 94 $13215-13220$.

Received 14 March 2000

Accepted 26 May 2000 